\title{
Structural and functional characterization of solution, gel, and aggregated forms of trypsin in organic solvent-assisted and $\mathrm{pH}$-induced phase changes
}

\author{
[Trpsinin çözelti, jel ve agregat formlarının organik çözgen içeren ve \\ $\mathrm{pH}$-tektiklenmiş faz geçişlerinde yapısal ve fonksiyonel incelenmesi]
}

\author{
Cagatay Ceylan ${ }^{1}$, \\ Bilge Karacicek ${ }^{2}$
}

'Department of Food Engineering İzmir Institute of Technology, İzmir, Turkey

${ }^{2}$ Department of Biotechnology, İzmir Institute of Technology, İzmir, Turkey

\section{Correspondence Address}

[Yazıșma Adresi]

\section{Çağatay Ceylan}

İzmir Institute of Technology, Department of Food Engineering, Urla, 35430, İzmir, Turkey.

Phone: +902327506328

Fax: +90 2327506196

E-mail: cagatayceylan@iyte.edu.tr
Registered: 21 May 2013; Accepted: 08 July 2014 [Kayıt Tarihi: 21 Mayıs 2013; Kabul Tarihi: 08 Temmuz 2014]

\begin{abstract}
Objective: In this study the effect of three different physicochemical parameters on $\mathrm{pH}$-triggered gelation and aggregation of bovine pancreatic trypsin phase changes and phase structural and functional changes in these phase changes in alcohol-water mixtures were studied.

Methods: Trypsin gelation times were studied using inverted tube method. Trypsin stability was studied using trypsin enzyme assay. Protein secondary structural changes were monitored using FTIR spectroscopy. Gel and aggregate macrostructures and morphologies were viewed using Scanning Electron Microscopy.

Results: The solution phase was observed in the absence of both $\mathrm{NaOH}$ and $\mathrm{CaCl}_{2}$. The gel phase was observed in the absence of the either. The aggregate phase was observed in the presence of the both agents all depending on trypsin concentrations used. Trypsin stability studies showed that there were a nearly 53 and $32 \%$ a specific activity losses after the gelation and aggregation processes. According to FTIR studies $\beta$-sheet structure in $1637 \mathrm{~cm}^{-1}$ band disappeared in trypsin gel and trypsin aggregates. Increases in $\alpha$-helix structure in $1651 \mathrm{~cm}-1$ in trypsin gel and aggregates were observed. Iodoacetamide delayed the gelation and prevented the aggregation indicating the importance of intermolecular disulfides in the both processes.

Conclusion: Trypsin gelation was caused by the denaturation of the protein three dimensional structures. The gel and aggregate formation indicates a secondary structural change towards $\alpha$-helix structure formation at the expense of $\beta$-sheet structure and formation of intermolecular disulfide bonds.
\end{abstract}

Key Words: Trypsin, Gelation, Aggregation, FTIR

Conflict of Interest: Authors have no conflict of interest.

\section{ÖZET}

Amaç: $\mathrm{Bu}$ çalışmada alkol-su karışımlarında $\mathrm{pH}$ tarafından tetiklenen sığır pankreatik tripsin jelleşmesi ve agregasyonu faz değişiklikleri üzerine üç değişik fizikokimyasal değişkenin yapısal ve fonksiyonel etkileri çalışılmıştır.

Metod: Tripsin jelleșmesi ters tüp metodu ile çalıșlmıștır. Tripsin stabilitesi tripsin enzim aktivitesi tayiniyle çalışılmıştır. Protein ikinci yapı değişiklikleri FTIR spektroskopisi metodu ile gözlenmiştir. Jel ve agregat makroyapıları ve morfolojileri taramalı elektron mikroskopisi yöntemiyle incelenmiştir.

Bulgular: $\mathrm{NaOH}$ ve $\mathrm{CaCl}_{2}$ eksikliğinde çözelti fazı gözlenmiştir. Jel fazı bu ikisinden birinin eksikliğinde gözlenmiştir. Agregat fazı ise bu iki ajanın birlikte varlığında tripsin konantrasyonuna bağlı olarak gözlenmiş̧ir. Tripsin dayanıklılık çalışmaları jelleşmede yaklaşık olarak $53 \%$ ve agregasyonda ise $32 \%$ özgül aktivitede dayanıklılık kaybı göstermiştir. FTIR spektroskopisi çalışmalarında tripsin jel ve agregatlarında $1637 \mathrm{~cm}-1$ daki $\beta$-yaprağ bantının yok olduğu görülmüştür. $1651 \mathrm{~cm}-1$ daki $\alpha$-heliks bantının güçlenmesi tripsin jel ve agregatlarındaki alfa helix artişına karşılık gelmektedir. Iodoasetamidin jelleşmeyi geciktirmesi jelleşmede moleküller arası disülfit bantlarının önemine işaret etmektedir.

Sonuç: Tripsin jelleşmesinin protein yapısındaki denatüreasyondan kaynaklandığı görülmüştür. Jel oluşumu protein ikincil yapısında $\beta$-yaprağı kaybına paralel olarak $\alpha$-heliks oluşumu ve moleküller arası disülfit bağlarının oluşumu ile gerçekleşmektedir.

Anahtar Kelimeler: Tripsin, Jelleşme, Agregasyon, FTIR

Çıkar Çatışması: Yazarların çıkar çatışması yoktur. 


\section{Introduction}

The fact that proteins are found in different physical forms (solutions, aggregated, gel and powder forms) due to different environmental conditions $(\mathrm{pH}$, ionic strength, or initial protein concentration) has been a very vivid scientific field of biochemistry for years. Due to the well-known structure-function relationship of proteins, function of a protein molecule is linked to environmental conditions. In addition the nature of protein-protein and protein-solvent interactions affect the fate of protein phase behavior.

Under certain conditions some proteins form gels or gellike structures are commonly recognized as an intermediary phase between solid and solution forms. Gels are regular structures and are composed of network connection of constituting individual particles [1]. Other conditions may also cause aggregation of the protein molecules which have amorphous physical appereance. As opposed to gelation, protein aggregation/precipitation is considered to be a phase separation resulting in formation of a solid phase in a solution [2-3]. The aim of this research is to compare the solution, gel and aggregate forms of trypsin obtained in three different environmental conditions using functional and structural means.

\section{Materials and Methods}

\section{Preparation of protein gel and aggregate}

Bovine pancreatic trypsin is a globular protein and has a molecular weight of 24,000 daltons. 223 amino acid residues in trypsin are interconnected by six disulphide bonds [4]. Throughout the experiments trypsin was dissolved in $1 \mathrm{mM} \mathrm{HCl}$ in the between the concentrations of $2 \mathrm{mg} / \mathrm{ml}$ and $10 \mathrm{mg} / \mathrm{ml}$. Then, isopropanol was added to the protein solution at a ratio of $1(\mathrm{vol} / \mathrm{vol})$. As a last step, $\mathrm{NaOH}$ was added to the protein-isopropanol mixture at the designated concentrations. Gelation and aggregation took place depending on the trypsin concentration, $\mathrm{CaCl}_{2}$ concentration and the $\mathrm{pH}$ of the solution.

\section{Inverted tube method}

Gelation time was determined when the gel in the tube did not flow or slip through the tube [5].

\section{Trypsin Enzyme Assay and Specific Activity}

Trypsin catalyzes the hydrolysis of N-benzoyl-L-arginine ethyl ester to N-benzoyl-L-arginine and ethanol. The slope of the absorbance versus time graph is the production rate of BA at $\mathrm{pH} 7.6$ and a total volume of $3.2 \mathrm{ml}$ for the reaction at $25^{\circ} \mathrm{C}$. The specific activity of trypsin is equal to (units of activity/ml of solution)/protein concentration $(\mathrm{mg} / \mathrm{ml})$. The unit of activity of trypsin activity is defined as $1 \mu \mathrm{mol}$ BA produced/minute of 0.001 at 253 $\mathrm{nm}$, at $\mathrm{pH} 7.6$ and at $25^{\circ} \mathrm{C}$. The reaction was carried out in $100 \mathrm{mM}$ Tris buffer solution with $20 \mathrm{mM} \mathrm{CaCl}_{2}$ in order to prevent autocatalysis in the conditions of the reaction. Trypsin concentration in solution was determined by UV absorbance at $278 \mathrm{~nm}$.

\section{Iodoacetamide (IAA) Studies}

Iodoacetamide (IAA) was used as the disulfide blocking agent [6]. $1 \mathrm{M}$ and $2 \mathrm{M}$ IAA were used for $5 \mathrm{mg} / \mathrm{ml}$ trypsin concentration to observe the gelation time-aggregation changes.

\section{Scanning Electron Microscopy (SEM) Studies}

Scanning Electron Microscope (SEM) images were obtained by using Quanta 250 FEG (FEI, USA). SEM images of trypsin, trypsin gel, and trypsin aggregate were taken at $20 \mu \mathrm{m}$ magnification. All the samples were dried for two days to get rid of the gel humidity. Later the dried samples of the original trypsin, trypsin gel, and trypsin aggregate were exposed to N2 gas (for coating) and were then analyzed under the SEM.

\section{FT-IR Spectroscopy and Spectral Analysis}

FTIR spectra of trypsin powder, aggregate and gel were recorded with a Perkin-Elmer Spectrum 100 FTIR spectrometer (Perkin-Elmer Inc., Norwalk, CT, USA) equipped with MIR TGS detector. The gel was lyophilized by Labconco FreeZone lyophilizator (Labconco, FreeZone 18 liter freeze dry system) for one night. 225 $\mathrm{mg} \mathrm{KBr}$ was mixed with $0.5 \mathrm{mg}$ trypsin. The mixture was then exposed to a pressure of $1100 \mathrm{~kg} / \mathrm{cm}^{2}$ in an evacuated die to produce a $\mathrm{KBr}$ pellet for use in FT-IR spectrometer. The spectra were recorded in the $4000-450 \mathrm{~cm}-1$ region at room temperature. A total of 20 scans were taken for each interferrogram at $4 \mathrm{~cm}-1$ resolution. Spectrum 100 software (Perkin-Elmer) was used for the data manipulations. From trypsin powder, gel and aggregate $(n=3)$ multiple scans, which gave identical spectra, were performed. These replicates were averaged and the averaged spectra for each sample were then used for further data manipulation and statistical analysis. The spectra were smoothed over 19 points using the Savitzky-Golay algorithm. Then, the spectra were interactively baselined from two arbitrarily selected points. Finally, the spectra were normalized in specific regions for visual comparison of the samples of the amide I bands.

For quantitative analysis of the secondary structures, the gel and aggregate protein secondary structure variations were determined based on intensity calculations from the second derivative spectra of amide I band (1700-1600 $\mathrm{cm}-1)$. The spectrum of the second derivation was performed by a Savitzky-Golay algorithm with five smoothing points. The second derivative peaks were normalized. The second derivative signals of the minima peak were used as the peak positions of the original absorption spectra correlation.

\section{Statistical Analysis}

The differences between the control and pressure treated groups were compared using the Mann-Whitney U Test with the Matlab R2011a program. The statistical results 
Table 1. The effect of iodoacetamide on gelation time and aggregation of trypsin at room temperature.

\begin{tabular}{lcc}
\hline IAA presence & No IAA & 1 M and 2 M IAA \\
Trypsin gel & 2.5 minutes & More than 40 minutes \\
Trypsin aggregate & Aggregation & No aggregation \\
\hline
\end{tabular}

were expressed as means \pm standard deviation. A $p$ value of less than 0.05 was considered statistically significant.

\section{Results}

The Phase Behaviour of Trypsin as a Function of Protein Concentration, $\mathrm{pH}$

and Ionic Strength: Three different phases were observed due to three different environmental factors: trypsin, $\mathrm{CaCl}_{2}$, and $\mathrm{NaOH}$ concentrations. Among these enviromental factors, $\mathrm{NaOH}$ concentration determines the $\mathrm{pH}$ of the solution, and $\mathrm{CaCl}_{2}$ concentration determines the solution's ionic strength. In Figure 1, the phase behavior of trypsin is visualized in three-dimensional space.

In general, gel form was observed between the solution and aggregate forms. Trypsin was shown to be in the solution state at low $\mathrm{NaOH}$ and $\mathrm{CaCl}_{2}$ concentrations. When the physicochemical conditions leading to aggregation and gelation were considered in all trypsin concentrations in the absence of both $\mathrm{NaOH}$ and $\mathrm{CaCl}_{2}$, solution phase was observed. In the presence of $\mathrm{CaCl}_{2}$ and in the absence of $\mathrm{NaOH}$, gelation was observed due to binding of $\mathrm{CaCl}_{2}$ binding to water. In contrast in the presence $\mathrm{NaOH}$ and in the absence of $\mathrm{CaCl}_{2}$, solution phase was observed due to the insufficient trypsin concentration. In all trypsin concentrations aggregation was observed in the presence of both $\mathrm{NaOH}$ and $\mathrm{CaCl}_{2}$. Gelation was observed in the presence of either $\mathrm{NaOH}$ or $\mathrm{CaCl}_{2}$ except for the $2 \mathrm{mg} / \mathrm{ml}$ trypsin concentration case. This might be because in the presence of $\mathrm{NaOH}$ and in the absence of $\mathrm{CaCl}_{2}$ gelation was not observed due to the insufficient trypsin concentration.

\section{Trypsin stability after gelation/resolubilization}

The specific activity measurements were performed to
Table 2. The band assignments of secondary structure sub-bands under Amide I band in $1700-1600 \mathrm{~cm}^{-1}$ region [7].

\begin{tabular}{lcc}
\hline Peak Number & Mean Frequencies $\left(\mathrm{cm}^{-1}\right)$ & $\begin{array}{c}\text { Assignment } \\
\text { Antiparallel } \\
1\end{array}$ \\
1694 & $\begin{array}{l}\beta \text {-sheets } \\
\text { Turns }\end{array}$ \\
3 & 1674 & a-helix \\
4 & 1652 & Random coil \\
5 & 1643 & $\beta$-sheets \\
6 & 1637 & Aggregated \\
& 1625 & $\beta$-sheets \\
\hline
\end{tabular}

compare the stability of the trypsin following gelation and resolubilization steps. The specific activities of the original trypsin and trypsin gel are shown in Figure 2. The decrease in the specific activity of trypsin was $53.25 \%$, following gelation and resolubilization. The loss in the specific activity indicated irreversible changes in trypsin structure due to phase changes. The decrease in the specific activity of trypsin in the aggregates was $32.45 \%$.

\section{Iodoacetamide (IAA) Studies}

Iodoacetemide was used as the disulfide bond blocking agent in protein related analyses to investigate the disulfide bond formation in the gelation process as a function of gelation time [6]. In addition, the presence of iodoacetamide prevented aggregation of trypsin. The results indicated that disulfide bonds were important both in the gel and formation processes as shown in Table 1.

\section{Fourier Transform Infrared Spectroscopy Studies}

FTIR method was applied to observe the secondary structural changes of trypsin which follows gelation and aggregation processes. Amide I band region (between 1600 $\mathrm{cm}-1$ and $1700 \mathrm{~cm}-1$ ) was taken into consideration for protein secondary structure analysis. The band assignments of the original trypsin, trypsin gel, and trypsin aggregate were carried out in the region between 1700-1600 $\mathrm{cm}-1$ which corresponded to the amide I region as shown in Figures $3 \mathrm{a}$ and $3 \mathrm{~b}$. The Amide I band secondary struc-

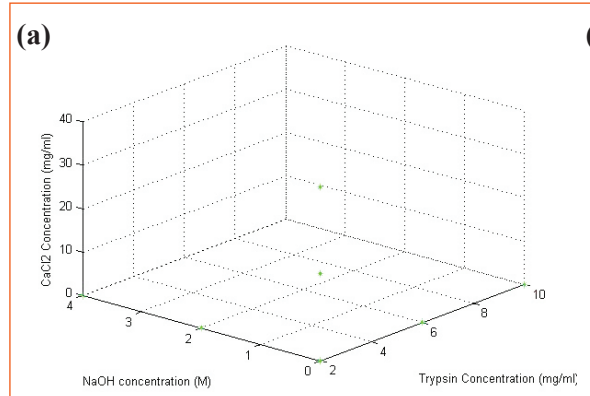

(b)

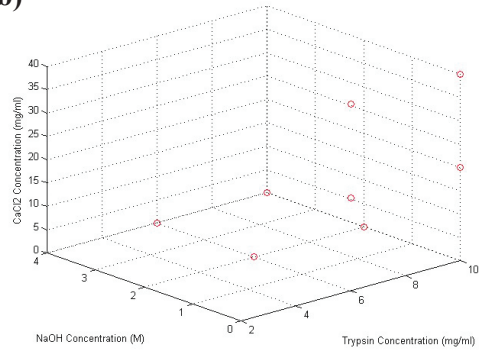

(c)

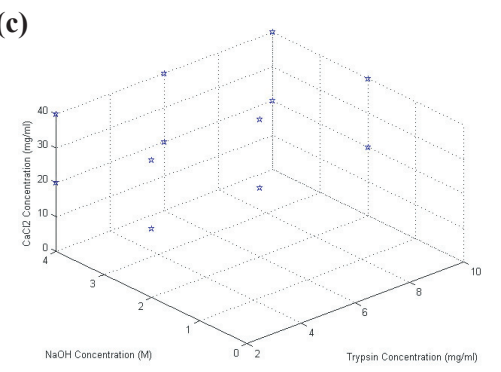

Figure 1. The phase behaviour of trypsin as a function of trypsin concentration, $\mathrm{pH}$ and ionic strength in the form of (a) solution (b) gelation, and (c) aggregation. 
Table 3. The results of the changes in the intensities of main protein secondary structures for original, gel and aggregated trypsin (Values are the mean \pm standard error of mean for each group).

\begin{tabular}{lccc}
\hline Functional Groups & Trypsin & Gelated Trypsin & Aggregated Trypsin \\
\hline Antiparallel $\beta$-sheets (at 1694 cm-1) & $-0.01386 \pm 0.00038$ & $-0.0081 \pm 0.00029$ & $-0.00233 \pm 0.0005$ \\
Turns (at 1674 cm-1) & $-0,01104 \pm 0.00029$ & $-0.00642 \pm 0.00063$ & $-0.00257 \pm 0.00021$ \\
a-helix (at 1652 cm-1) & $-0.01 \pm 0.00011$ & $-0.00497 \pm 0.000367$ & $-0.0045 \pm 0.00056$ \\
Random coil (at 1643 cm-1) & $-0.00978 \pm 0.00063$ & $-0.00798 \pm 0.001$ & $-0.00277 \pm 0.00025$ \\
$\beta$-sheets (at 1637 cm-1) & $-0.0167 \pm 0.0003$ & $-0.00565 \pm 0.0003$ & $-0.00253 \pm 0.00035$ \\
Aggregated $\beta$-sheets (at 1625 cm-1) & $-0.00956 \pm 0.00009$ & $-0.0069 \pm 0.0011$ & $-0.0026 \pm 0.00026$ \\
\hline
\end{tabular}

tural assignments of the spectra are shown in Table 2. The changes in the intensities of the bands for the secondary structures are shown in Table 3 .

As seen in Figure 3a, the gel shows changes in secondary structure of trypsin. However, the most significant changes were observed when the second derivative spectra were taken into consideration (Figure $3 b$ ). The $\beta$-sheets at $1637 \mathrm{~cm}-1$ were found to be the ones most affected from the gelation process. The trypsin gel was found to have $32.30 \%$ less $\beta$-sheet structure $(\mathrm{p}<0.05)$. However, the aggregated and anti parallel $\beta$-sheet structures were shown to increase by $25.61 \%$ and $14.29 \%$ in gels respectively $(p<0.05)$. Random coil structure was also observed to increase $(36.06 \%)$ significantly $(p<0.05)$. There was no percentage change in the percent $\alpha$-helix structure in the gel structure $(\mathrm{p}>0.05)$. Turns structure showed a $10.79 \%$ increase in the gel phase. The aggregate also showed changes in secondary structure. The aggregate spectra showed a significant band shift in the average spectra compared to the trypsin control spectrum. When the second derivative spectra was taken into consideration, $\beta$-sheets which appeared at $1637 \mathrm{~cm}-1$ were found to be the ones most affected from aggregation process as seen in Figure $3 \mathrm{~b}$. The trypsin aggregate was also found to have $43.52 \%$ less $\beta$-sheet structure $(\mathrm{p}<0.05)$. Similarly the antiparallel $\beta$-sheet structure $(29.16 \%)(\mathrm{p}<0.05)$ and turns $(8.8 \%)$ $(p<0.05)$ were adversely affected by aggregation. How-

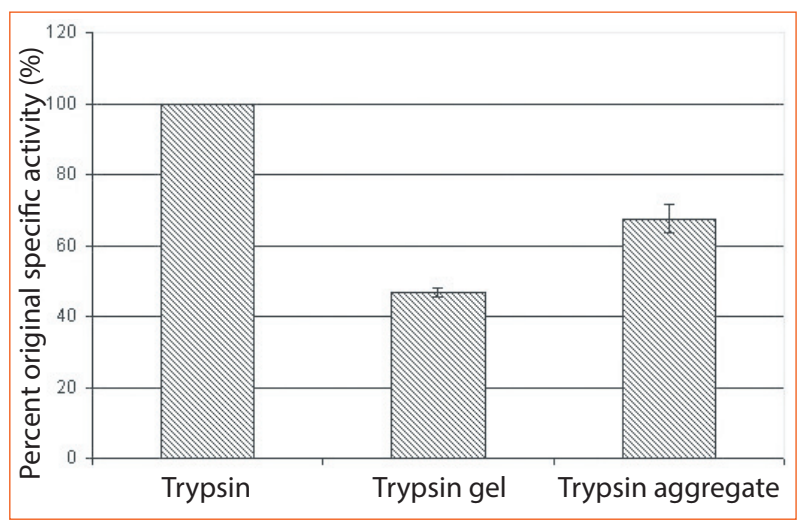

Figure 2. Trypsin stability after gelation and aggregation at $25^{\circ} \mathrm{C}$.

ever, the aggregated $\beta$-sheets were not affected by trypsin aggregation $(\mathrm{p}>0.05)$. In contrast to $\beta$-sheets, $\alpha$-helix structure was shown to increase significantly (30.49\%) $(p<0.05)$ and random coils increased slightly $(2.99 \%)$ $(\mathrm{p}>0.05)$.

\section{Scanning Electron Microscopy (SEM) Studies}

The SEM images of trypsin in gel and aggregated phases were analyzed to observe the effect of the gelation and aggregation processes on solid phase trypsin morphology. The SEM images were taken at the magnifications of $20 \mu \mathrm{m}$ and the results are shown in Figure 4. The origi-
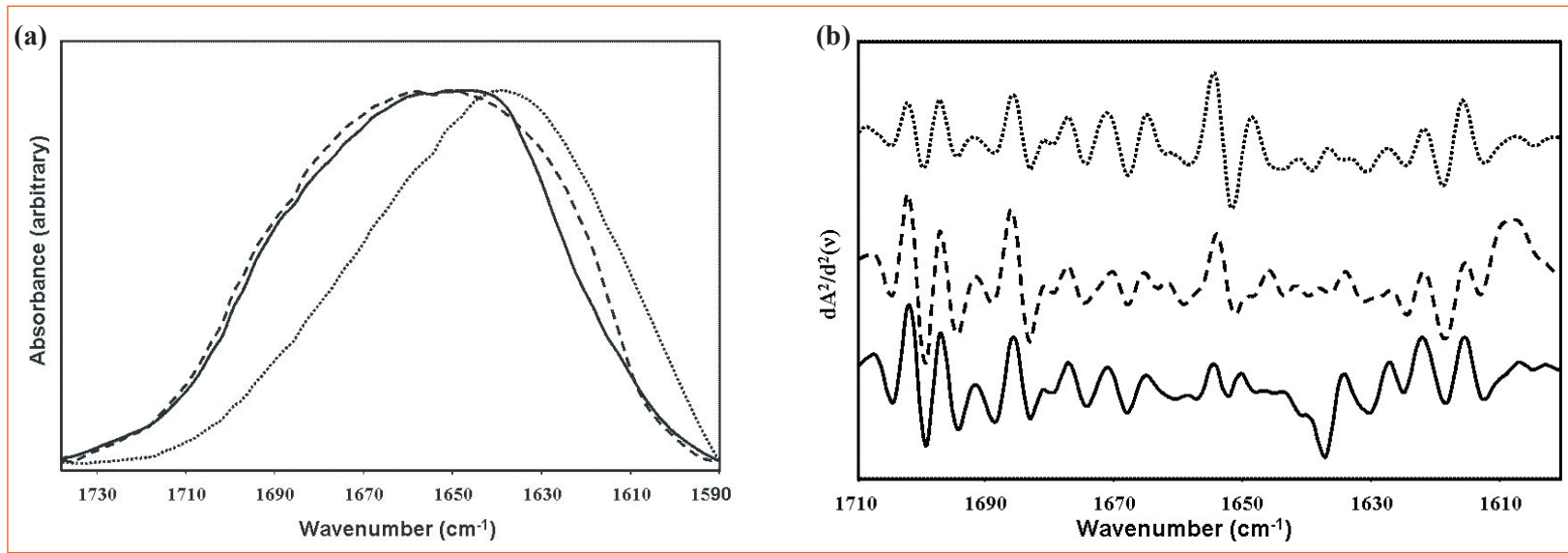

Figure 3. The average (a) absorbance and (b) second derivative spectra of original trypsin, trypsin gel and trypsin aggregate in 1700-1600 $\mathrm{cm}-1$ region (continuous line shows original trypsin, dashed line shows trypsin gel, dotted line shows trypsin aggregate). 

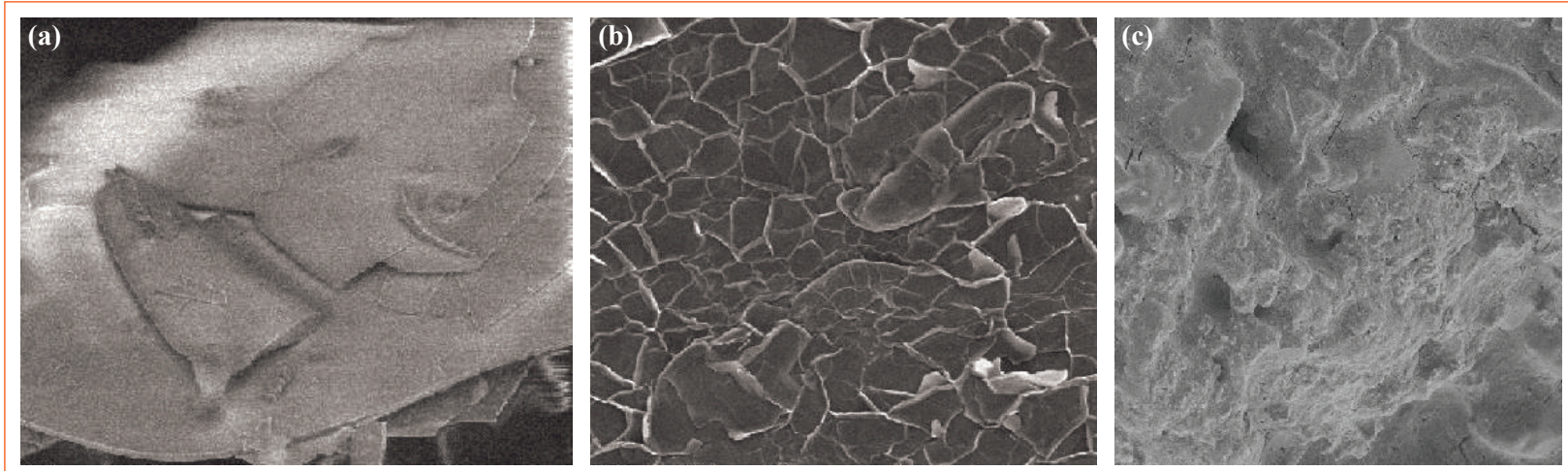

Figure 4. SEM images of (a) original trypsin, (b) trypsin gel, and (c) trypsin aggregate at $20 \mu \mathrm{m}$ magnifications.

nal trypsin flakes were observed as thin sheets under the SEM. The SEM images of the gel after drying appeared to have a smoother surface appearance. As seen in the same figure, trypsin aggregates appeared to have an amorphous structure.

\section{Discussion}

In all of the trypsin concentrations studied, the solution phase was observed in the absence of $\mathrm{NaOH}$ and $\mathrm{CaCl}_{2}$. Gelation was observed in the presence of either $\mathrm{CaCl}_{2}$ or $\mathrm{NaOH}$. At higher trypsin concentrations $(6 \mathrm{mg} / \mathrm{ml}$ and 10 $\mathrm{mg} / \mathrm{ml}$ ) gelation was observed because sufficient trypsin concentration for gelation was provided (in the absence of $\mathrm{CaCl}_{2}$ ). Aggregation was observed in the presence of both $\mathrm{NaOH}$ and $\mathrm{CaCl}_{2}$. The results were summarized in a tabular form in Table 4.

The results seem to indicate that at lower $\mathrm{CaCl}_{2}$ concentrations $(2,6$ and $11 \mathrm{mg} / \mathrm{ml}) \mathrm{CaCl}_{2}$ caused neutralization of electrostatic interactions and three dimensional network formations which resulted in gelation. At high $\mathrm{CaCl}_{2}$ concentrations $(22,33,44$ and $55 \mathrm{mg} / \mathrm{ml})$ where $\mathrm{CaCl}_{2}$ concentration was in excess for neutralisation, the same charged ions in trypsin molecules started to repel each other and rather than gelation aggregation was observed. Since $\mathrm{CaCl}_{2}$ binds to water and as the $\mathrm{CaCl}_{2}$ concentration increased it could hold more water molecules by decreasing the water concentration in protein solution and led to increased protein concentrations simultaneously by increasing the protein-protein interactions. Since $\mathrm{CaCl}_{2}$ held the distances between water and trypsin molecules shorter, gelation was observed. In cold-set gelation

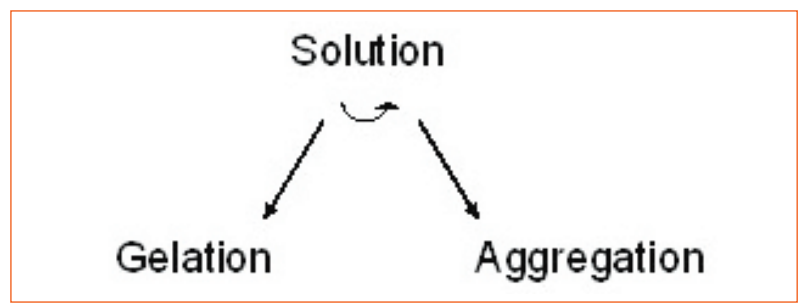

Figure 5. The proposed model for trypsin phase behavior. of whey proteins many different salts such as $\mathrm{CaCl}_{2}$ are commonly used $[8,9] . \mathrm{CaCl}_{2}$ addition to medium causes neutralization of electrostatic interactions in whey protein gel formation [10]. In a study with whey proteins, it was observed that at low $\mathrm{CaCl}_{2}$ concentrations $(10 \mathrm{mM}$ or lower than $10 \mathrm{mM}$ ), gelation was slow and ordered, fine stranded gels were obtained. At high $\mathrm{CaCl}_{2}$ concentrations (higher than $10 \mathrm{mM}$ ), gelation was fast and aggregates were obtained [11]. At high salt concentrations, electrostatic repulsion between protein molecules screened sufficiently so that protein molecules could come closer to form aggregates [18]. Gelation becomes slower as $\mathrm{CaCl}_{2}$ concentration reached at low $\mathrm{CaCl}_{2}$ concentrations as in Kuhn's work [11]. Also Kuhn observed aggregates at high $\mathrm{CaCl}_{2}$ concentrations.

Protein initial concentration is also an important variable in protein phase changes. Higher trypsin concentrations yielded more interactions between trypsin molecules. As trypsin concentration increased the interaction with the other trypsin molecules, gelation occurred in much shorter times than at lower trypsin concentrations.

Solution $\mathrm{pH}$ is another important variable in protein stability and phase behavior [12]. According to Figure 2b, the increasing $\mathrm{NaOH}$ concentration leads to a decrease in trypsin solubility and gelation took place. As solubility of trypsin molecules decreased their interaction with each other and environment increased. As a result, a decrease in gelation time was observed. This finding was expected when the basic nature of trypsin is considered $(\mathrm{pI}=10.5)$. When the solution $\mathrm{pH}$ is near the $\mathrm{pI}$, random aggregation formation is observed. Protein concentration and salt type

Table 4. Trypsin phase behaviour for different $\mathrm{CaCl}_{2}$ and $\mathrm{NaOH}$ concentrations.

\begin{tabular}{ccc}
\hline $\mathrm{NaOH}$ Presence & $\mathrm{CaCl}_{2}$ Presence & Phase Behaviour \\
+ & + & Aggregation/Gelation \\
+ & - & Solution/Gelation \\
- & + & Solution/Gelation \\
- & - & Solution \\
\hline
\end{tabular}


affects the network formation [13]. According to the experimental observations a model was proposed (Figure 5). Upon triggering of the $\mathrm{pH}$ change three different phase behaviors were observed: solution phase, gelation and aggregation. Since different initial conditions led to trypsin molecules assumed three different phase behaviors. It was supposed that gelation and aggregation occurred through different molecular mechanisms. This conclusion was further supported by the fact that these different mechanisms resulted in different structural organizations as appeared in the FTIR spectra.

The specific activity results indicated that trypsin partially lost its activity irreversibly after gelation and aggregation.

The FTIR spectroscopy results indicated that $\alpha$-helix structure was found to increase in the aggregation process. This is an unexpected situation since in the most of the protein aggregation studies the amount of $\alpha$-helix was found to decrease in favor of $\beta$-sheet structures [14]. In most of the neurological diseases and other metabolic diseases, $\beta$-sheets are the structures leading to the aggregation processes both in vivo and in vitro conditions [15, $16,17,18,19]$. As opposed to the aforementioned studies trypsin aggregates were found to have lower $\beta$-sheet structures with higher $\alpha$-helix content in this study.

In our study it was observed that in the presence of IAA, gelation was delayed and also soft gels were formed (Table 1). Since trypsin contains six intramolecular disulfide bonds, the possible roles of intra and inter-molecular disulfide bond formation in the gelation process between trypsin molecules were investigated. Similarly, it is known that disulfide bond formation increases gel hardness. It is well known that protein-protein interactions leading to aggregation are strongly affected by intermolecular $\beta$-sheets and disulfide reshuffling. Therefore, intermolecular disulfide bond formation might be responsible for the intermolecular interactions in trypsin gelation and aggregation. Iodoacetamide was found to affect disulfide bonding by thiol blocking. In protein chemistry, it is known that when thiol groups are blocked, disulfide bonding can not take place [6]. In proteins, disulfide bonds are formed by the introduction and removal of the thiol-disulfide exchange reaction [20]. Under adverse physicochemical conditions such as high pressure, temperature, sulfhdryl and cystine groups in proteins are exposed to the surrounding environment and hence facilitate their reaction to form disulfide bonds [20].

\section{Conclusion}

Trypsin was shown to form three different phases (solution, gel, and aggregate) for three different physicochemical variables (protein concentration, $\mathrm{pH}$, and ionic strength) in the same experimental system (pH-triggered and alcohol-induced phase change). This system made it possible to investigate the protein structural changes and morphological differences for the three different phases.
Contrary to the most of the previous studies, $\alpha$-helix structures were shown to increase during the phase changes when compared with the solution phase, indicating no contribution from any inter/intra molecular $\beta$-sheet structures. Instead, trypsin phase changes were shown to be driven by inter/intra molecular disulfide trypsin structure.

\section{Acknowledgements}

This study is supported by İzTech Scientific Research Council (BAP) with the project number 2011IYTE11. Trypsin was purchased with funds from İzTech Scientific Research Council (BAP) with the project number 2008IYTE22. We thank İzmir Institute of Technology (İzTech) Biotechnology and Bioengineering Central Research Laboratories for providing us the necessary facilities throughout the experiments. We also thank the Department of Chemistry for allowing us to use the FTIR spectrometer. In this study, the experimental work was carried out by Bilge Karaçiçek as her Masters Thesis in İzmir Institute of Technology and the study was proposed and guided by Asst. Prof. Dr. Çağatay Ceylan.

\section{Conflict of Interest}

There are no conflicts of interest among the authors.

\section{References}

[1] Hongsprabhas P, Barbut S, Marangoni AG, The Structure of ColdSet Whey Protein Isolate Gels Prepared With Ca++. Lwt-Food Sci Technol 1999; 32(4):196 - 202.

[2] Page MJ, Cera ED, Combinatorial Enzyme Design Probes Allostery and Cooperativity in the Trypsin Fold. J Mol Biol 2010; 399 (2):306-319.

[3] Mendoza MD, Ortego F, Lacoba MGD, Poza DL, Farinos GP, Castanera P, Crespo PH. Diversity of trypsins in the Mediterranean corn borer Sesamia nonagrioides (Lepidoptera: Noctuidae), revealed by nucleic acid. Insect Biochem Molec 2005; 35:10051020 .

[4] Epstein CJ, Anfinsen CB. The reversible reduction of disulfide bonds in trypsin and ribonuclease coupled to carboxymethyl cellulose 1962; 237(7):2175-2179.

[5] Lawal OS. Functionality of African locust bean (Parkia biglobossa) protein isolate: effects of $\mathrm{pH}$, ionic strength and various protein concentrations. Food Chem 2004; 86:345-355.

[6] Alting AC, Hamer RJ, de Kruif CG.M, Paques M, Visschers RW. Number of thiol groups rather than the size of the aggregates determines the hardness of cold set whey protein gels. Food Hydrocolloid 2003; 17:469-479.

[7] Garip Ş, Yapici E, Ozek N Ş, Severcan M, Severcan F. Evaluation and discrimination of simvastatin-induced structural alterations in proteins of different rat tissues by FTIR spectroscopy and neural network analysis. Analyst 2010; 135(12):3233-3241.

[8] Boulet M, Britten M, Lamarche F. Aggregation of some food proteins in aqueous dispersions: effects of concentration, $\mathrm{pH}$ and ionic strength. Food Hydrocolloid 2000; 14:135-144.

[9] Hongsprabhas P, Barbut S. Ca+2-induced cold gelation of whey protein isolate: effect of two-stage gelation. Food Res Int 1998; 30:533-527.

[10] Maltais A, Remondetto GE, Gonzalez R, Subirade M. Formation of Soy Protein Isolate Cold-set Gels: Protein and Salt Effects. J Food Sci 2005; 70:67-73. 
[11] Kuhn KR, Cavallieri ALFC, da Cunha RL. Cold-set whey protein gels induced by calcium or sodium salt addition. Int J Food Sci Tech 2010; 45:348-357.

[12] Choi YS, Cho MS, Park JW. Effect of Hydration Time and Salt Addition on Gelation Properties of Major Protein Additives. J Food Sci 2000; 65:1338-1342.

[13] Hongsprabhas P, Barbut S. Effects of N-ethylmaleimide and $\mathrm{CaCl}_{2}$ on cold gelation of whey protein isolate. Food Res Int 1997; $30: 451-455$

[14] Wang W. Protein aggregation and its inhibition in biopharmaceutics. Int J Pharm 2005; 289:1-30.

[15] Honson NS, Johnson RL, Huang W, Inglese J, Austin CP, Kureta J. Differentiating Alzheimer disease-associated aggregates with small molecules. Neurobiol Dis 2007; 28:251-260.
[16] Huang THJ, Yang DS, Plakos NP, Go S, Yip CM, Fraser PE, Chahrabartty A. Structural Studies of Soluble Oligomers of the Alzheimer ß-Amyloid Peptide. J Mol Biol 2000; 297:73-87.

[17] Morgan C, Colombresa M, Nunez MT, Inestrosa NC Structure and function of amyloid in Alzheimer's disease. Prog Neurobiol 2004; 74:323-349.

[18] Serpell LC. Review: Alzheimer's amyloid fibbrils: structure and assembly. Biochimica et Biophysica Acta 2000; 1502:16-30.

[19] Uversky VN, Fink AL. Review Conformational constraints for amyloid fibrillation: the importance of being unfolded. Biochim Biophys Acta 2004; 1698:131-153.

[20] Hansen RE, Winther JR. An introduction to methods for analyzing thiols and disulfides: Reactions, reagents, and practical considerations. Anal Biochem 2009; 394:147-158. 